\title{
Palm Kernel De-Oiled Cake: A Potential Source of Cellulose for the Production of Carboxylmethyl Cellulose for Industrial Uses
}

\author{
Ikechukwu Kingsley Ubaoji, Ndika Vincent Ezea, Chidozie Sunday Umerie \\ Department of Applied Biochemistry, Faculty of Biological Sciences, Nnamdi Azikiwe University Awka, Anambra State, \\ Nigeria \\ Email: ezeavincentndika@gmail.com
}

How to cite this paper: Ubaoji, I.K., Ezea, N.V. and Umerie, C.S. (2020) Palm Kernel De-Oiled Cake: A Potential Source of Cellulose for the Production of Carboxylmethyl Cellulose for Industrial Uses. Open Access Library Journal, 7: e6810. https://doi.org/10.4236/oalib.1106810

Received: September 10, 2020

Accepted: December 11, 2020

Published: December 14, 2020

Copyright $\odot 2020$ by author(s) and Open Access Library Inc.

This work is licensed under the Creative Commons Attribution International License (CC BY 4.0).

http://creativecommons.org/licenses/by/4.0/

\begin{abstract}
The problem of over dependence on foreign raw materials such as Carboxylmethyl cellulose for Nigerian industries has been a big threat to the country's economy. In order to curtail the menace, this work aims at the production of Carboxylmethyl cellulose which serves as a thickening agent, emulsifier, stabilizer, extender etc. from palm kernel de-oiled cake. Palm kernel de-oiled cake was converted to Carboxylmethyl cellulose (CMC), a derivative of cellulose by two reaction steps, mercerization and etherification. Some quality control parameters were assayed on the produced CMC. Fourier Transform Infra-red Spectroscopy (FT-IR) was used to characterize the produced Carboxylmethyl cellulose and the commercial grade CMC as control. Paint formed using CMC was assessed in terms of viscosity, $\mathrm{pH}$, and compared with paint formed using commercial CMC. Carboxylmethyl cellulose is a highly specific substrate for the endo-acting cellulase and its catalytic product (glucose) was assayed using a simple reducing sugar assay such as 3,5-dinitrosalycylic assay. The results of the CMC at the first etherification gave a degree of substitution and kinematic viscosity of $0.65 \pm 0.02$ and 70.46 \pm 1.20 , while at second etherification, the values obtained were $1.0 \pm 0.01$ and $80.0 \pm 1.00$ against the values obtained from the commercial grade which were given as $1.7 \pm 0.05$ and $95.0 \pm 0.04$ respectively. The result of the FT-IR of the CMC (test) and the commercial CMC shows similarities at a wavelength of $600-4000 \mathrm{~cm}^{-1}$ with slight differences. The presence of CMC was quantitatively confirmed by the activity of cellulase enzyme on the product which was estimated by colour development using 3,5-dinitrosalicyclic acid and read at $540 \mathrm{~nm}$. The results of the $\mathrm{CMC}$ showed no significant differences with the commercial grade using a one-way test (ANOVA) $p>0.05$. The results showed that palm kernel cake can be a better source of cellulose for the
\end{abstract}


production of CMC which would find many applications in food, drug, paint, paper and allied industries.

\section{Subject Areas}

Biological Chemistry

\section{Keywords}

Carboxylmethyl, Cellulose, Glucose, Palm Kernel Cake, Commercial Grade, Degree of Substitution, Derivatives

\section{Introduction}

Cellulose is a long chain of linked sugar molecules that can provide strength for all kinds of plant [1]. It is the main component of plant cell walls, and the basic building block for many commercial products such as textiles, packaging, explosives, paper and many more [1]. At molecular level, cellulose is a simple linear polymer consisting of D-anhydroglucopyranose unit (AGU) linked together with $\beta$-(1,4)-glycosidic bonds formed between carbon 1 and carbon 4 of adjacent glucose. In the solid state, AGU units are rotated $180^{\circ}$ with respect to each other due to the constraints of $\beta$-linkage. Each of the AGU units consists of three hydroxyl groups at carbon 2, 3 and 6 positions. The hydroxyl group at carbon 1 of either end of molecule is an aldehyde group which has a reducing characteristic. Cellulose has no taste, no odor, hydrophilic, insoluble in water and most organic solvents, chiral and biodegradable. It was shown to melt at $467^{\circ} \mathrm{C}$ [2]. It can be broken down chemically into its glucose units by treating it with concentrated acids at high temperature or enzyme hydrolysis. In cellulosic plant fiber, most mammals have only very limited ability to digest dietary fibers such as cellulose by themselves, that seems to be why humans excrete freely after they were fed with fiber rich food. In many herbivorous animals such as ruminants like cattle and sheep and hindgut fermenters like horses, cellulases are produced by symbiotic bacteria. Some animals, particularly ruminants and mollusks, degrade cellulose with the help of cellulases found in their guts [3]. Cellulases are produced by a few types of animals, such as some termites [4] [5]. The cellulosic compounds from plants can then be integrated into complex cellulosic compounds known as cellulose derivatives. These cellulose derivatives are developed so that it can be soluble in water or dilute alkali and thus can be utilized as finishing and sizing agents for textiles, as absorbable surgical gauze, protective colloids, adhesives, thickening agents for foods, creams, ointments and pastes and many other industrial applications. Palm kernel cake for example in nature is a type of agricultural by-product that is very rich in its cellulose property and thus can be converted into a valuable industrial raw material. The cellulose part of the palm kernel cake can subsequently be integrated into a derivative of a cellulosic compound such as carboxymethyl cellulose (CMC). CMC is a water-soluble fiber at 
room temperature. This present research work focuses on the production of Carboxmethyl cellulose from palm kernel cake (PKC) which is an agricultural by-product, which is gotten after the palm kernel oil extraction. It is a highly fibrous and medium grade protein feed, hence most suited to ruminant or rabbit feeding [6]. In some places, palm kernel cake is seen as a waste product while in some places, it is mainly used in farm animal nutrition for poultry and piggery among others. They are also used as a source of energy to fire boilers industries. Presently it is underutilized and with highly limited applications. There is therefore the need to find novel and more sublime applications in order to diversify its utilizations and increase its revenue base. In Nigeria, research showed that there is no indigenous commercial production of Carboxylmethyl cellulose (CMC). The reason may be ignorance on particular readily available primary raw materials for the production, thereby making Nigerian industries over dependent on importation of carboxylmethyl cellulose. This factor necessitated this research on the conversion of palm kernel cake which is an agricultural by-product, into CMC. There had been various researches which had executed a similar experimental approach (i.e. synthesis of carboxymethyl cellulose) using alternative raw materials other than wood. Most of these researches did not investigate or subject their CMC product into saleable/industrial product in other to ensure the quality of their produced CMC whilst this research work incorporated the produced $\mathrm{CMC}$ in industrial decorative paint production. There are two main processes when synthesizing CMC from PKC, first of all, the cellulosic compounds in the palm kernel cake are required to be isolated so that it would not interrupt the production of CMC. Other than cellulose, palm kernel cake also comprises of hemicelluloses as well as lignin, these two undesirable compounds needed to be removed so that only solely celluloses will be acquired. When the celluloses are finally obtained, the process of converting cellulose into a derivative compound can be assembled.

\section{Materials and Instruments}

\subsection{Materials}

Palm kernel cake was obtained from a local palm kernel oil mill factory at Ogbete Main Market Enugu, Enugu State of Nigeria. It was first dried in sun light and then ground in mortar and then sieved using $355 \mu \mathrm{m}$ laboratory sieve. The mature giant African land snails (Achatina achatina) were collected from a farm land at Akpugo Ezedike community, Uzo-Uwani LGA of Enugu State. The snails were identified as giant African land snail (Achatina achatina) by Dr. T.C Mogbo from the Department of Zoology Faculty of Biological Sciences, Nnamdi Azikiwe University, (NAU) Awka.

\subsection{Reagents/Chemicals}

Analytical grade chemicals used in this experiment include hydrochloric acid ( $\mathrm{HCl}$, Merck, Germany), distilled water, $\mathrm{H}_{2} \mathrm{O}$, sodium hydroxide ( $\mathrm{NaOH}$, Merck, 
Germany), Glucose $\left(\mathrm{C}_{6} \mathrm{H}_{12} \mathrm{O}_{6}\right)$ Sigma Aldrich Chemical Ltd England, Dinitrosalicychlic acid (DNS) $\left(\mathrm{C}_{7} \mathrm{H}_{4} \mathrm{~N}_{2} \mathrm{O}_{7}\right)$ Avighkar, India, Carboxylmethyl cellulose (BDA Chemical ltd Pool England), electrical balance (SPB 31, Kaifeng Group Co. Ltd.), ostwald's viscometer (Ernst Haage), hot plate stirrer (Thermolyne Mirak), electric wall oven (temperature EOEM61AS, Electrolux), digital spindle rotothinner viscometer.

\section{Methods}

Extraction of cellulose from palm kernel cake.

Step 1. Sample de-fatting. The sample was first of all defatted following the procedure described by [7].

Procedure: The Palm Kernel cake sample weighing $152.67 \mathrm{~g}$ was weighed into a $1000 \mathrm{ml}$ flat bottom flask. Then $200 \mathrm{ml}$ of $\mathrm{n}$-hexane was introduced into the sample and the sample shaken vigorously until the whole sample was completely submerged in the n-hexane. The mixture was covered using foil and allowed to stand for $24 \mathrm{hrs}$ for complete fat/oil extraction. The n-hexane containing the dissolved oil was gradually decanted from the sample and the sample was allowed to dry overnight at ambient temperature.

The $\%$ oil or fat content was calculated as:

$$
=\frac{\text { Loss of oil after de-fating }}{\text { Weight of sample before de-fating }} \times 100
$$

\section{Step 2: Removal of lignin.}

A $129.27 \mathrm{~g}$ of the oil free palm kernel was mixed with $100 \mathrm{ml}$ distilled water, $100 \mathrm{ml}$ glacial acetic acid and $50 \mathrm{~g}$ of sodium chlorite. The mixture was stirred for 2 hours at $75^{\circ} \mathrm{C}$. The residue was filtered and washed with $200 \mathrm{ml}$ of $95 \%$ ethanol and $100 \mathrm{ml}$ of distilled water. This step was repeated. Similarly, the washed palm kernel is dried in an oven at $60^{\circ} \mathrm{C}$ for 24 hours. This was done according to [8] with slight modification.

Calculation of lignin \% is given as

$$
=\frac{W_{3}-W_{4}}{W_{3}} \times 100
$$

where $\mathrm{W}_{3}$ is the initial weight of the sample,

$\mathrm{W}_{4}$ is the final weight of the sample after drying.

Step 3: $\mathrm{NaOH}$ Pretreatment. (removal of hemicelluloses).

$\mathrm{NaOH}$ pretreatment was carried out following the method by [8]. The lignin free Palm Kernel Cake weighing $121.83 \mathrm{~g}$ was weighed into a flat bottom round flask, to which $500 \mathrm{ml}$ of $18 \% \mathrm{NaOH}$ solution was added and stirred vigorously at room temperature for $30 \mathrm{~min}$. During stirring, the flask was covered with aluminum foil, and afterwards filtered using a vacuum pump and then washed with 500 $\mathrm{ml}$ of $20 \%$ acetic acid in hot water, and washed again with hot distilled water.

The hemicelluloses were determined using the equation

$$
=\frac{W_{5}-W_{6}}{W_{5}} \times 100
$$


where $W_{5}$ is the initial weight of the sample,

$W_{6}$ is the final weight of the sample after drying.

\section{Step 4: Bleeching with hydrogen peroxide.}

The bleaching was done by the procedure of [9] with slight modification. The Palm Kernel Cake $50 \mathrm{~g}$ was weighed into a three neck round bottom flask and $250 \mathrm{ml}$ of $7.5 \% \mathrm{w} / \mathrm{v}$ of hydrogen peroxide was introduced into the weighed sample. A reflux condenser was fitted into the middle neck of the flask, the whole mixture refluxed at $90^{\circ} \mathrm{C}$ for $2 \mathrm{hrs}$. After $2 \mathrm{hrs}$, the sample was allowed to cool and filtered using a vacuum pump. The residue was further washed with hot water.

After the defatting, removal of lignin and hemicelluloses, the remaining sample is cellulose.

\subsection{Production of Carboxylmethyl Cellulose}

The procedure for the CMC production was modified from the procedure used by [10]. The extracted cellulose from PKC was then converted to CMC in two steps; alkalization (mercerization) and etherification of cellulose under heterogeneous conditions. In alkalization pretreatment, $26.25 \mathrm{~g}$ of the extracted cellulose was introduced into a glass reactor together with $336 \mathrm{ml}$ of isopropanol and $30.6 \mathrm{ml}$ of distilled water. The impeller was held at $350 \mathrm{rpm}$ for an hour, and a reflux condenser was mounted at the glass reactor to avoid evaporation. After 15 mins, $10.05 \mathrm{~g}$ of $\mathrm{NaOH}$ was mixed with $15.3 \mathrm{ml}$ of deionized water and then 58.5 $\mathrm{ml}$ of isopropanol was added to the solution. The solution was left at $30^{\circ} \mathrm{C}$ for 24 hrs.

In the next step, under the etherification process, $73.5 \mathrm{ml}$ of $87 \%$ of isopropanol was mixed with $38.50 \mathrm{~g}$ of NaMCA. Before being added to the reaction mixture, the temperature was raised for a period of $30 \mathrm{mins}$ to $60^{\circ} \mathrm{C}$ and then left for 60 mins at $60^{\circ} \mathrm{C}$. For the second etherification process, $40.5 \mathrm{~g}$ of NaMCA was still added to the reaction mixture. The reaction was terminated by neutralization with the addition of $80.5 \mathrm{ml} 70 \%$ acetic acid.

After filtration, the product (NaCMC) was washed with $350 \mathrm{ml}$ of $87 \%$ isopropanol, $350 \mathrm{ml}$ of $70 \% \mathrm{MeOH}$, and finally with $350 \mathrm{ml}$ pure methanol. To confirm that all sodium contained by the products, such as $\mathrm{NaCl}$ and $\mathrm{C}_{2} \mathrm{H}_{3} \mathrm{NaO}_{3}$ had been removed from the washed CMC sample, $100 \mathrm{ml}$ of $\mathrm{AgNO}_{3}$ solution was added gradually to the sample of the final washed filtrate and stirred until no $\mathrm{AgCl}$ precipitation appeared. Thus the only remaining sodium ions were those that belonged to the substituted CMC.

\subsection{Quality Control Test on the Produced Carboxylmethyl Cellulose}

The produced CMC was tested for the following qualities and was compared with the commercial brand.

\section{5. $\mathrm{pH}$ Measurement}

It is important to determine the $\mathrm{pH}$ value of this sodium salt to know the level of 
alkalinity or acidity.

\section{Method:}

A $0.5 \mathrm{~g}$ of the CMC was dissolved in $25 \mathrm{ml}$ of distilled water and the $\mathrm{pH}$ was measured using a Mettler Toledo $\mathrm{pH}$ meter.

\subsection{Determination of Degree of Substitution}

Method: The determination of the degree of substitution was carried out according to the method of [11]. The Carboxylmethyl Cellulose $(0.84 \mathrm{~g})$ calculated as oven dried product, was ashed at $700^{\circ} \mathrm{C}$ for $20 \mathrm{mins}$, the ash was dissolved in $42 \mathrm{ml}$ boiling deionized water before titrated with $0.1 \mathrm{n}_{2} \mathrm{SO}_{4}$, using electronic $\mathrm{pH}$ meter, until the solution reached a $\mathrm{pH}$ of 4.4. The DS was then calculated from the amount of titrated acid $(\mathrm{b} / \mathrm{ml})$ and the amount of CMC $(\mathrm{G} / \mathrm{g})$.

$$
D S=\frac{0.162\left(\frac{0.1 b}{G}\right)}{1-0.080\left(\frac{0.01 b}{G}\right)}
$$

\subsection{Cold Water Solubility}

The determination of the cold water solubility was carried out according to the method of [11]. A $0.5 \mathrm{~g}$ of the CMC sample was soaked in $25 \mathrm{ml}$ of cold water; the mixture was kept for $6 \mathrm{hrs}$, filtered, allowed to dry under $105^{\circ} \mathrm{C}$ in an oven and reweighed after cooling. The solubility of the CMC was determined using the formula and result recorded.

$$
\% \text { solubility }=\frac{\text { loss in weight }}{\text { Volume of water }} \times 100
$$

\subsection{The Kinematic Viscosity was Determined Using Ostwald Type Viscometer}

The determination of the viscosity was modified from the method used by [12]. Viscosity is a measure of the resistance of a fluid to deformation under shear stress. It describes a fluid's internal resistance to flow and is a measure of fluid friction.

A $2 \mathrm{~g}$ of the CMC sample was dissolved in $25 \mathrm{ml}$ of water and the viscosity was determined using U-TUBE viscometer. The Kinematic viscosity was determined using Ostwald type viscometer.

Procedure: The viscometer was filled with $25 \mathrm{ml}$ of the dissolved sample through tube L to slightly above the mark G, using a long pipette to minimize wetting the tube above the mark. The U-tube was placed vertically in a water bath maintained at room temperature for 30 mins to allow the temperature reach equilibrium. The volume of the liquid was adjusted so that the bottom of the meniscus settled at the mark G. The liquid was blown to a point about 5 $\mathrm{mm}$ above the mark $\mathrm{E}$. Then, the time taken for the bottom of the meniscus to fall from the top edge of mark $\mathrm{E}$ to the top edge of mark $\mathrm{F}$ was measured from the u-tube Ostwald viscometer. Then the viscosity was calculated in square 
millimeter per second $\left(\mathrm{mm}^{2} \cdot \mathrm{s}^{-1}\right)$.

$$
\text { Calculation }=V=K T
$$

where $T=$ Time in seconds from the meniscus to fall from $E$ to $F, K$ is the constant of the instrument which is determined on a liquid of known viscosity.

\subsection{The Moisture Content was Analyzed by the AOAC (1990) Method}

There are many methods for the determination of the moisture contents, but the drying method was used for this research.

The moisture content was determined using the method described by [12].

Principle: This method is used to determine the percentage of water in a sample by drying the sample to a constant weight.

Procedure: A $1 \mathrm{~g}$ of the each sample (CMC and MCC) was weighed and poured into the petri dish. The dishes with the samples were kept in an oven at $105^{\circ} \mathrm{C}$, until a constant weight were obtained. The dried samples were cooled in the desiccators. This is to prevent absorption of moisture from the environment since the cellulose is hydroscopic. The samples were reweighed after cooling.

$$
M C=\frac{\text { Wet Wt }- \text { Dry Wt }}{\text { Wet Wt }} \times 100
$$

where Wet $\mathrm{Wt}=$ initial weight of the specimen.

Dry $\mathrm{Wt}=$ final or oven dried weight of the specimen.

\subsection{Ash Contents Determination}

The method as described by [12] was used to determine the Ash content determination.

Principle: The pre ground test sample is weighed into crucibles and placed into a muffle furnace. The ashing is carried out and is completed when the cool residue is white or nearly white.

Procedure: Empty platinum crucibles were washed and dried in an oven at $80^{\circ} \mathrm{C}$. It was cooled in the desiccators. Later, it was weighed and recorded. A $1 \mathrm{~g}$ of the samples were measured into the platinum crucible and put in a furnace and set at $600^{\circ} \mathrm{C}$, it was ashed for $4 \mathrm{hrs}$. Percentage ash contents were calculated as

$$
=\frac{W_{7}-W_{8}}{W_{7}} \times 100
$$

where $W_{7}$ is the weight of the sample before drying,

$W_{8}$ is the final weight of the sample after drying.

Note: Two confirmatory tests were carried out to ensure that what was produced was actually CMC, they are FT-IR and use of CMC in decorative water based paint production.

\subsection{Paint Formation (SCMC BONDED PAINT)}

The quality of the produced Carboxylmethyl cellulose was also tested by using 
the produced CMC to produce paint. The paint was produced according to the method described [13]. The CMC acted as a viscosity modifier and as well as the binding strength of the paint. The quality control test (viscosity, pH, S.G, wet abrasion tester, caking and settlement after production, spreading rate) were conducted after the production.

The quantity of the raw materials used for the production is listed below and each raw material was stirred for about 5 mins using electrical stirrer before the addition of the subsequent raw material. Water $500 \mathrm{ml}$, Calgon PT (NaHMP) 1.8 g, $\mathrm{TiO}_{2} 35 \mathrm{~g}$, Genepour $0.75 \mathrm{ml}$, Defoamer $2.25 \mathrm{ml}, \mathrm{CaCo}_{3} 740 \mathrm{~g}$, Acrylic rasin $87.50 \mathrm{ml}$.

These materials were weighed repeatedly into three different buckets. $7 \mathrm{~g}$ of SCMC (commercial) was dissolved in one portion of the weighed materials. $7 \mathrm{~g}$ of CMC (Test sample) was dissolved in the second portion. The third portion was CMC free. After then, $2 \mathrm{ml}$ of ammonia was added in each portion.

\subsection{Characterization of the Produced Carboxymethyl Cellulose by Fourier Transform Infra-Red Spectroscopy (FTIR)}

The FTIR technique is an important tool used to identify the characteristics functional groups, which are instrumental in elucidating of functional groups and organic compounds inherent in any tested sample. This study is thus aimed at showcasing the functional groups and compounds present in the extracted Carboxylmethyl Cellulose (CMC).

Infra-red spectra of the CMC samples were recorded with Shimadzu FTIR-8210 PC. Pellets were made from CMC samples $4 \mathrm{~g}$ was ground with $700 \mathrm{~g}$ of KBR. Transmission was measured at the wave number range of $400-6000 \mathrm{~cm}^{-1}$.

\subsection{Isolation of Cellulase from the Digestive Tracts of Achatina achatina}

Dissections of the snails were carried out by the method described by [14]. The snails were deshelled and their digestive glands (hepatopancreas) were removed. The removed gland was suspended in $50 \mathrm{Mm}$ sodium acetate buffer, $\mathrm{pH} 5.5$ and homogenized using an electronic blender. The homogenate was centrifuged at $5000 \mathrm{rpm}$ for $15 \mathrm{~min}$ at $4^{\circ} \mathrm{C}$. The supernatant was collected as crude enzyme (cellulase).

\subsection{Partial Purification of the Enzyme by Ammonium Sulfate Precipitation}

Principle: Ammonium sulfate stabilizes proteins by preferential solvation. When the ammonium $\left(\mathrm{NH}_{4}{ }^{+}\right)$and sulfate $\left(\mathrm{SO}_{4}{ }^{2-}\right)$ ions are within the aqueous solution they are attracted to the opposite charges evident on the compound that is being purified. This attraction of opposite charges prevents the water molecules from interacting with the compound being purified, leading to the precipitation or "salting out".

Procedure: The crude enzyme was partially purified following the method by 
[14] with slight modifications. The crude enzyme was brought to $40 \%$ ammonium sulphate saturation. The ammonium sulphate $(100 \mathrm{ml})$ was pipette into a test tube that contains the cellulase, it was shaken continuously until precipitate occurred. It was further centrifuged at $5000 \mathrm{rpm}$ for $15 \mathrm{~min}$.

\subsection{Removing of Ammonium Sulfate by Dialysis}

Principle: A dialysis bag made of a semipermeable membrane (cellulose) and has small pores. The bag is filled with a concentrated solution containing proteins. Molecules that are small enough to pass through the pores of the membrane diffuse out of the bag into the buffer solution, or dialysate. The molecules go from an area of high concentration to low concentration. When the level of concentration is equal between the bag and the buffer, there is no more net movement of molecules.

Procedure: The method by [14] was used. The precipitate was dissolved in 50 $\mathrm{Mm}$ Na-acetate buffer $\mathrm{pH} 5.5$, a $50 \mathrm{ml}$ of the enzyme solution was put in a cellophane bag and immersed in a $250 \mathrm{ml}$ of the same buffer and stirred, it was dialyzed overnight in the same buffer with a change of the buffer every 6 hrs, after which the enzyme was tested by its activities on the cellulose derivative (CMC) both the produced CMC and the commercial CMC.

\section{Enzyme Assay}

\subsection{Total Cellulase Activity Assay}

The total cellulose activity was assayed according to the method of [14] with slight modification. The assay mixture was made of $2 \mathrm{ml}$ of $50 \mathrm{Mm} \mathrm{Na-acetate}$ buffer, pH 5.5 and $0.5 \mathrm{ml}$ of the enzyme. A strip of filter paper was immersed into the assayed mixture and incubated in a water bath at $50^{\circ} \mathrm{C}$ for 30 mins after which $0.5 \mathrm{ml}$ of DNS reagent was added. The assay mixture was then boiled in a temperature controlled water bath for $10 \mathrm{mins}$, cooled and the absorbance was then read at $540 \mathrm{~nm}$.

\subsection{Endo- $\beta$-1,4-Glucase Activity Assay (Carboxylmethyl Cellulose Assay)}

The endoglucanase activity assay was carried out according to the method of [14]. A $0.1 \mathrm{ml}$ of $1 \%$ Carboxylmethyl cellulose (test sample) was pipetted into a test tube followed by the addition of $0.1 \mathrm{ml}$ of the enzyme. This was incubated in a temperature controlled water bath at $50^{\circ} \mathrm{C}$ for 30 mins. The reaction mixture was then made up to $2.5 \mathrm{ml}$ with $50 \mathrm{mM} \mathrm{Na}$-acetate buffer, $\mathrm{pH} 5.5$. Then $0.5 \mathrm{ml}$ of DNS reagent was added and the reaction mixture was boiled in a temperature-controlled water bath for 10 mins, cooled and the absorbance was read at $540 \mathrm{~nm}$. The procedure was repeated for commercial CMC and for graded concentration of glucose (for standard curve). This was also repeated in each step of the partial purifications, (ammonium sulfate precipitation and dialysis). All the experiments were done in triplets. 


\subsection{5 mM Glucose Standard Curve}

From the stock solution containing $5 \mathrm{mg}$ of glucose, $0.5,1,1.5,2,2.5,3,3.5,4$, 4.5 , and $5 \mathrm{ml}$ was pipette into different test tubes, in a decreasing order distilled water was added into each test tubes to make the solutions up to $5 \mathrm{ml}$ before adding $1 \mathrm{ml}$ of DNS plus $1 \mathrm{ml}$ of Rochelles salt to each tube before boiling for 20 mins. It was cooled and the absorbance was read at $540 \mathrm{~nm}$. The graph of absorbance against concentration which starts from the origin was plotted and the values of the glucose absorbance were extrapolated from the curve.

\subsection{Glucose Estimation}

Glucose concentration was estimated using the dinitrosalcyclic acid (DNS) methods by [15].

\section{STATISTICAL ANALYSIS}

Results of the study were expressed as mean \pm standard deviation. Differences between means of both the produced CMC and the control (commercial CMC) in this study were analyzed using a one way Analysis of Variance (ANOVA) of SPSS 16.0 spread sheet statistical package. Values were taken to be significant at $\mathrm{p}<0.05$.

\section{Results}

\subsection{Chemical Composition of the Palm Kernel Cake}

The chemical composition of the Palm Kernel de-oiled cake showed that the lipid, lignin, hemicelluloses and cellulose contents were $15.09 \%, 4.79 \%, 14.60 \%$ and $63.83 \%$ respectively. The yield of cellulose extracted from the palm kernel de-oiled cake, measured based on the dry weight basis was obtained after oil extraction, removal of lignin and hemicelluloses. From the value of the cellulose yield, it shows that palm kernel de-oiled cake has a high range of a-cellulose which will improve the quality of the cellulose derivatives. After oil extraction, removal of lignin, and hemicelluloses, the remaining weight of the Palm Kernel de-oiled cake was $63.83 \%$. This represents that the amount of the unwanted material is $35.07 \%$. Table 1 shows the chemical composition of the palm kernel de-oiled cake.

\subsection{Characteristics of the Produced Carboxylmethyl Cellulose and the Commercial Carboxylmethyl Cellulose}

From the results (Table 2) obtained at the $1^{\text {st }}$ etherification process, the degree of substitution, kinematic viscosity, $\mathrm{pH}$ and cold water solubility were given as 0.65 $\pm 0.02,558.4 \pm 5.91,8.57 \pm 0.01$ and $70.46 \pm 1.27$ respectively which was very low when compared with the control which was given as $1.7 \pm 0.55,800.8 \pm 0.45,6.4$ \pm 0.30 and $95.0 \pm 0.04$ respectively but at the $2^{\text {nd }}$ etherification, there was no significant different $(\mathrm{p}<0.05)$ when compared with the commercial grade, meaning that the quality improves at the $2^{\text {nd }}$ etherification. 


\subsection{Comparison of the FTIR Spectra of CMC Test Sample and the Commercial CMC}

Table 3 shows the corresponding peak values of carboxymethyl cellulose from palm kernel cake and the commercial CMC. From the table of results shown

Table 1. Chemical composition of the palm kernel de-oiled cake.

\begin{tabular}{cc}
\hline Tests & Values \\
\hline Lipid/fat content (\%) & $15.09 \pm 0.24$ \\
Lignin (\%) & $4.79 \pm 0.08$ \\
Hemicelluloses (\%) & $14.60 \pm 0.23$ \\
Cellulose (\%) & $63.83 \pm 0.97$ \\
\hline
\end{tabular}

Values are given as mean \pm S.D of the three determinations.

Table 2. Characteristics of the produced Carboxylmethyl cellulose and the commercial Carboxylmethyl cellulose.

\begin{tabular}{cccc}
\hline Parameters & $\mathbf{1}^{\text {st }}$ etherification & $\mathbf{2}^{\text {nd }}$ etherification & Commercial CMC \\
\hline $\mathrm{pH}$ & $8.57 \pm 0.01$ & $7.5 \pm 0.02$ & $6.4 \pm 0.30$ \\
Kinematic Viscosity $\left(\mathrm{mm}^{2} / \mathrm{S}^{-1}\right)$ & $558.4 \pm 5.91$ & $600.2 \pm 3.55$ & $800.8 \pm 0.45$ \\
Cold water solubility (\%) & $70.46 \pm 1.27$ & $80.01 \pm 1.00$ & $95.0 \pm 0.04$ \\
Degree of substitution & $0.65 \pm 0.02$ & $1.0 \pm 0.01$ & $1.7 \pm 0.55$ \\
Ash content (\%) & $16.07 \pm 0.33$ & $4.07 \pm 0.02$ & $3.50 \pm 0.60$ \\
Moisture (\%) & $3.11 \pm 0.11$ & $3.45 \pm 1.00$ & $3.01 \pm 0.01$ \\
\hline
\end{tabular}

Values are given as mean \pm S.D of the three determinations. The significance of the products were determined based on the $p$ value with $\mathrm{p}$ less than $0.05(\mathrm{p}<0.05)$ showing no significant differences.

Table 3. The correspondisng peak values for both CMC test sample and the commercial CMC.

\begin{tabular}{ccc}
\hline \multirow{2}{*}{ Functional groups } & \multicolumn{2}{c}{ Wavelenghts } \\
\cline { 2 - 3 } & CMC (test) & CMC (commercial) \\
\hline Chloro compound C-Cl stretch & 719.0474 & 755.5179 \\
Ether CO stretch & 843.5541 & 872.3141 \\
Vinylidine C=C anti-symetric stretch & 1335.44 & 1394.299 \\
Carboxylic acid CO stretch & 2002.637 & 2056.229 \\
Carbonyl compound & 2145.372 & 2273.180 \\
10 alcohol OH stretch & 3075.476 & 3011.466 \\
30 amine NH stretch & 3211.315 & 3452.856 \\
30 alcohol OH stretch & 3424.544 & 3557.237 \\
30 alcohol OH stretch & 3630.496 & 3808.803 \\
Methylene CH stretch & 2686.292 & 2604.162 \\
Nitriles CN anti-symmetric stretch & 2472.825 & 2483.585 \\
Cyclic ester CO stretch & 1747.612 & 1836.135 \\
\hline
\end{tabular}


below, the peak at $719.0474 \mathrm{~cm}^{-1}$ and $843.5541 \mathrm{~cm}^{-1}, 1335.44 \mathrm{~m}^{-1}$, and 2002.637 are assigned to $\mathrm{C}-\mathrm{Cl}$ and $\mathrm{CO}$ stretch of chloro, vinylidine compounds and carboxylic compound which correspond with the peak values of the commercial CMC $(755.5179,872.3141,1394.299,2056.229)$. The presence of strong absorption band at $2002.637 \mathrm{~cm}^{-1}$ in the FTIR spectrum is due to the COO-group. It is an evidence that hydroxyl group of cellulose was replaced with carboxyl group when carboxymethylation reaction occur (Figure 1). Spectrum in Figure 2, proves that the sample is $\mathrm{CMC}$ because it has a fingerprint region for CMC bonds of the commercial CMC.

\subsection{The Quality Control Assessments of the Produced CMC Bonded Paint}

From the results of the quality control tests conducted, the value of the viscosity, specific gravity, spreading rate and binding capacity were given as 9.8, 1.05, 10 $\mathrm{m}^{2} / 1$ and 505 strokes of wet abrasion scrub tester respectively as shown in Table 4 against the values obtained from the commercial grade with the values of 11.5, $1.0,11 \mathrm{~m}^{2} / 1$ and 600 strokes of wet abrasion scrub tester. From the values of the CMC (test) paint, it showed no significant difference with the CMC (commercial) paint $(\mathrm{p}<0.05)$. The paints were monitored for six months to check the

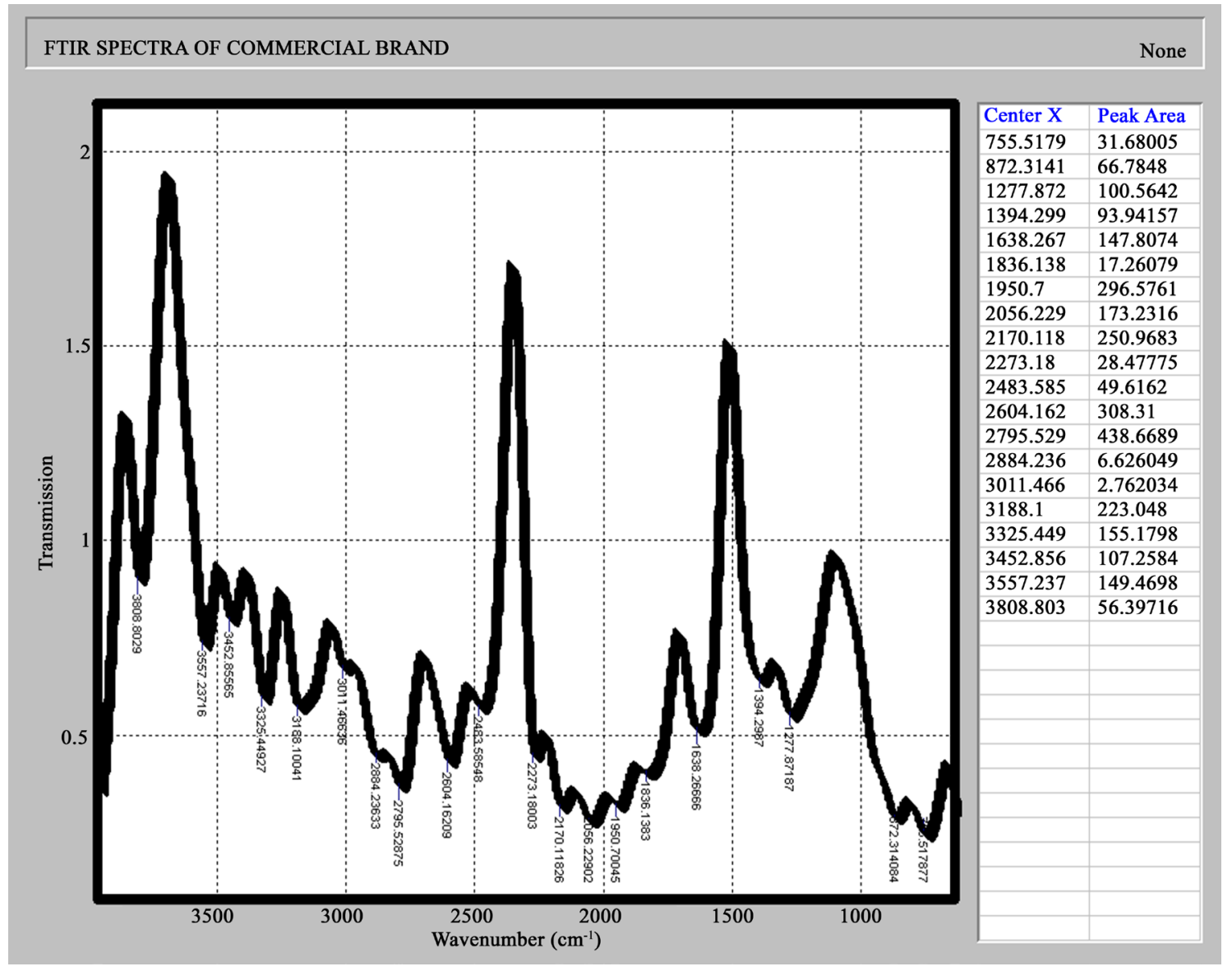

Figure 1. FTIR spectra of the commercial grade of carboxylmethyl cellulose. 


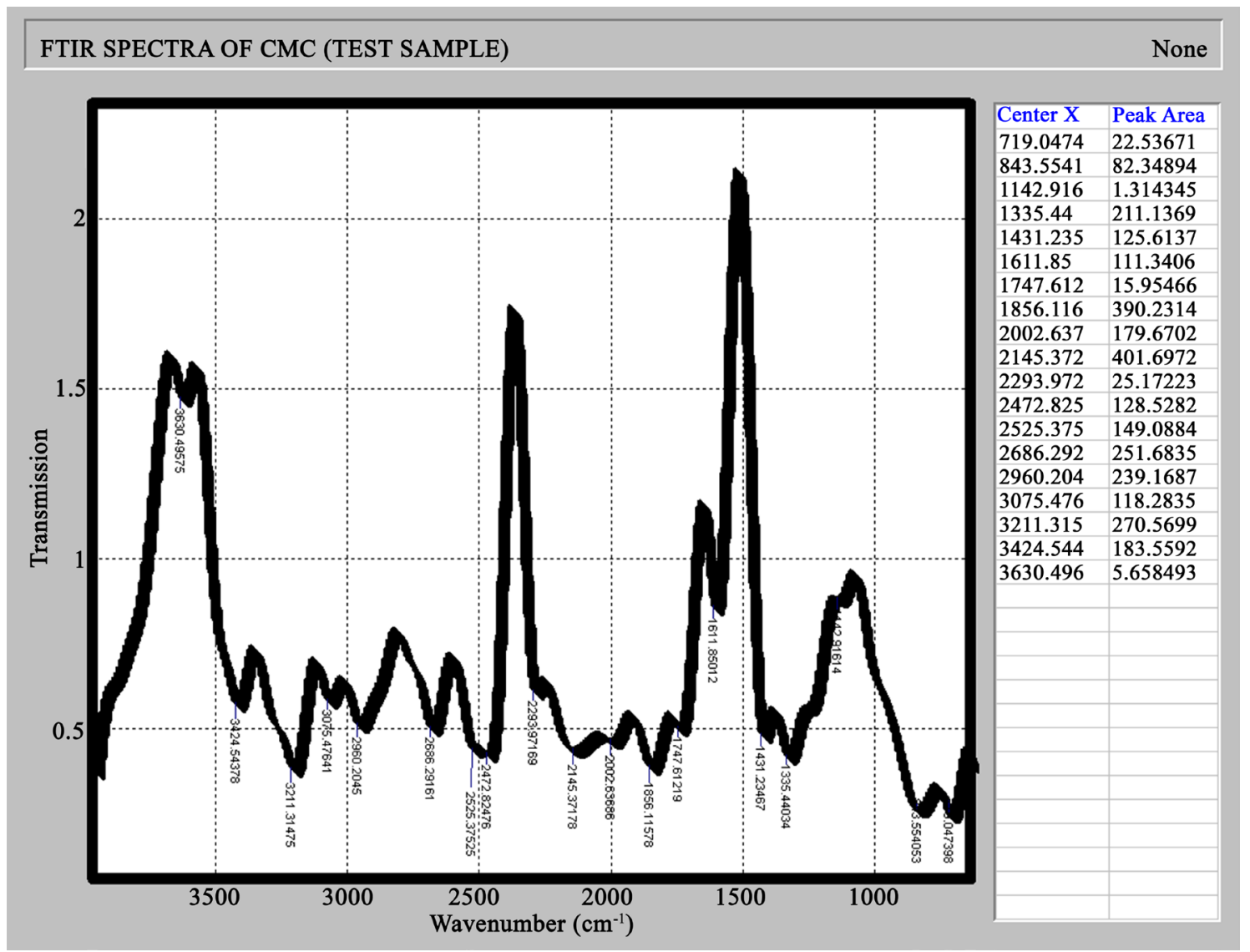

Figure 2. FTIR spectra of the produced carboxylmethyl cellulose (test sample).

Table 4. The quality control tests of the CMC bonded paint.

\begin{tabular}{ccccc}
\hline & \multicolumn{4}{c}{ Paint Samples } \\
\cline { 2 - 5 } Parameters & $\begin{array}{c}\text { With CMC } \\
\text { (test) }\end{array}$ & $\begin{array}{c}\text { With CMC } \\
\text { (commercial) }\end{array}$ & Without CMC & $\begin{array}{c}\text { NIS specification } \\
\text { (with CMC) }\end{array}$ \\
\hline Viscosity & $9.80 \pm 0.10$ & $11.50 \pm 0.20$ & $5.00 \pm 0.10$ & $8-12$ \\
pH & $8.9 \pm 0.02$ & $8.00 \pm 0.01$ & $4.5 \pm 0.02$ & $7.5-9.5$ \\
Spreading Rate $\left(\mathrm{m}^{2} / \mathrm{l}\right)$ & $10 \pm 0.01$ & $11 \pm 0.03$ & $12 \pm 0.02$ & $9-11$ \\
Specific gravity & $1.05 \pm 0.03$ & $1.0 \pm 0.04$ & $0.85 \pm 0.04$ & $1.0-1.5$ \\
B/C(strokes) & $505 \pm 0.20$ & $600 \pm 0.20$ & $150 \pm 0.30$ & $>500$ \\
\hline
\end{tabular}

Values are given as mean \pm S.D of the three determinations.

durability of the paint samples.

\subsection{Glucose Yield as a Reducing Sugar}

In Table 5, effect of cellulase activity determined by its effect on carboxylmethyl cellulose with respect to glucose formation, revealed that at crude enzyme, the amount of glucose recovered from the cellulase catalysis on the CMC (test) was lower $(774 \mathrm{mg} / \mathrm{l})$ when compared with the D-glucose recovered from the commercial CMC $(882 \mathrm{mg} / \mathrm{l})$. It was observed that the purer the enzyme, the greater 
Table 5. Glucose yield (as reducing sugar).

\begin{tabular}{cccc}
\hline \multirow{2}{*}{ Sample } & \multicolumn{3}{c}{ yield of $\mathrm{N}$-glucose $(\mathrm{mg} / \mathrm{l})$} \\
\cline { 2 - 4 } & Crude enzyme & $\left(\mathrm{NH}_{4}\right)_{2} \mathrm{SO}_{4}$ & Dialysis \\
\hline CMC & $774 \pm 0.02$ & $974 \pm 0.01$ & $1080 \pm 0.20$ \\
CMC (Commercial) & $882 \pm 0.60$ & $1044 \pm 0.03$ & $1152 \pm 0.04$ \\
\hline
\end{tabular}

Values are given as mean \pm S.D of the three determinations.

the glucose yield. At ammonium sulfate precipitation, the glucose yield were 972 $\mathrm{mg} / \mathrm{l}$ (test CMC), and $1044 \mathrm{mg} / \mathrm{l}$ (control), after dialysis, the glucose yield were $1080 \mathrm{mg} / \mathrm{l}$ (test) and $1152 \mathrm{mg} / \mathrm{l}$ (control), as were estimated from the $5 \mathrm{mM}$ glucose standard curve.

\section{Discussion}

From the value of the cellulose yield, it showed that palm kernel de-oiled cake has a high range of $\alpha$-cellulose which will improve the quality of the cellulose derivatives. The cellulose yield was lower compared with the cellulose gotten from Sorghum caudatum carried out by [16], but higher value was observed on the cellulose from PKC after the characterization of CMC produced from Picea abies (spruce) by [10], based on the original material used in the production process. The percentage yield of the cellulose from PKC was higher (98\%) than the 90\% of cellulose required for good quality cellulose derivatives. The a-cellulose according to [17] should be greater than $90 \%$ for the production of high quality cellulose derivatives. Lower $\alpha$-cellulose content implies the presence of low molecular oligosaccharides, which may affect the yield and quality of the derivative [18]. The yield depends upon the source of the cellulose. According to the result obtained, there was a higher content of hemicelluloses in palm kernel cake than what was observed from Cotton linter pulp which was carried out by [17] this suggested that acetic acid and $\mathrm{NaOH}$ used for the elimination of the hemicelluloses must be enough during the production for proper removal of the hemicelluloses if not, it will impose a serious problem on the cellulose derivatives. As an oil seed, palm kernel cake contained high fat content that was why it was subjected into solvent extraction otherwise known as palm kernel de-oiled cake. Cellulose prepared from this research study has an off white color, this observation contradicted with the brilliant white color obtained by [17], though the color of the cellulose depends upon the cellulose source and the nature of the bleaching that was applied. Cotton linter pulp according to [17] represents the brightest and purest form of cellulose source which gives it the advantage over other sources but with high cost of production and not readily available when compared with the palm kernel cake.

From the percentage yield of the cellulose derivatives, it was shown that the yield of CMC product from the palm kernel cake (Table 2) was high compared with the work of [19], but lower with the value gotten by [17], though, this may either be as a result of the source of the cellulose used or as a result of much de- 
gradation during the reaction period. According to [19], the yield of cellulose derivatives is certainly the function of the amount of material lost during dialysis step. Sodium carboxymethyl cellulose was produced from a heteregenous reaction where its rate is dependent upon the diffusion rate of the reagents $\mathrm{NaOH}$ and $\mathrm{CHClCH}_{2} \mathrm{COONa}$ inside the cellulose particles.

From the experimental parameters on the characteristics of the produced $\mathrm{CMC}$ and the commercial CMC, the results were comparable $(\mathrm{p}>0.05)$ to that of commercial grade of CMC. The quality of the cellulose derivative (CMC) improved at the second etherification. The values obtained at the first etherification are lower when compared with the values obtained after the second etherification (Table 3). At the first etherification, the cellulose derivative (CMC) was partially insoluble in water, and this suggested that the intermolecular and intramolecular hydrogen bond of the cellulose had not yet been broken, meaning also that neither of the 3 hydroxyl group in the anhydroglucose unit was substituted by the etherifying agent (MCA). The value of the degree of substitution in palm kernel cake of this study was higher when compared with the works of [10] [20]. Similar value of DS was observed from the work of [21] when their CMC was subjected to second round of etherification, but [17] reported a high value of the DS, though, the variations maybe as a result of the cellulose source, amounts of NaMCA used or concentration of $\mathrm{NaOH}$. According to [10], a direct correlation exist between the concentration of $\mathrm{NaOH}$ at the mercerization stage and the degree of substitution, he pointed out that when higher concentration of $\mathrm{NaOH}$ is used, it will result in higher value of the DS. The higher the Degree of Substitution, the higher the solubility of the cellulose derivative. However, substitution with alkyl groups reduces the number of free hydroxyl groups [22]. [20] Pointed out that when the DS is below 0.4, the CMC would be swellable but insoluble, while above this value, CMC is fully soluble with its hydro affinity increasing with increasing DS. The DS value for CMC from palm kernel de-oiled cake was 0.65 after the first etherification, obviously, it was fully soluble in water and its solubility increased after the second etherification this was in accordance with [23]. Degree of substitution represents the number of the carboxymethyl groups in the molecular unit of the anhydroglucose units. In principal, all hydroxyl groups (HO-2, HO-3, and HO-6) in the anhydroglucose unit can be substituted, and the maximum degree of substitution (DS) is 3 [24]. The value obtained for the total ash was very high compared with the commercial grade and as well as the value obtained by [17], the higher value may possibly be as a result that the cellulosic material was not almost free of inorganic compounds.

The FT-IR spectrum of both the produced CMC and commercial CMC showed resemblance in their wavelengths (Table 4). The presence of strong absorption band at $2002.637 \mathrm{~cm}^{-1}$ in the FTIR spectrum is due to the COO-group. It is an evidence that hydroxyl group of cellulose was replaced with carboxyl group when carboxymethylation reaction occur. Spectrum in Figure 1 proves that the sample is CMC because it has a similar wavelength peaks in the finger- 
print region for CMC bonds of the commercial CMC.

The applications of the CMC in paint impacted a remarkable binding strength of the paint, viscosity modified, improved the shelf life of the paint, and prevented caking and settlement of paint during storage. From the paint production, it was observed that the CMC functioned better in an alkaline environment. During the production, the effect of the CMC was delayed until a base (ammonia solution) was added into the mixture. This means that the function of ammonia solution in paint is not only to serve as preservative but also helps to hasten the activity of CMC. The quality control tests results obtained from both the produced paint using the CMC from palm kernel cake and its commercial grade showed that both the tested CMC and the control (commercial grade) CMC met the Nigerian industrial standard (NIS) quality control specification for a quality paint (Table 4).

The effect of cellulase activity determined by its effect on carboxylmethyl cellulose with respect to glucose formation revealed that carboxylmethyl cellulose was actually produced from palm kernel cake. From the enzyme catalysis, the amount of glucose recovered from the CMC (test) was lower compared with the D-glucose recovered from the CMC (commercial). From the glucose standard curve, it was observed that the higher the absorbance, the higher the concentration (yield). The crude enzyme yielded low glucose than purified enzyme. This means that the absorbance of the crude enzyme was lower which resulted in low yield. This suggested that the purer the enzyme, the higher the glucose yield. Furthermore, the results obtained from the hydrolytic action of the cellulase enzyme on the cellulose derivative suggested that cellulase from the digestive tracts of achatina achatina could serve as an ideal feed supplement which should be incorporated into some animal feeds to improve the nutritional values of high fiber feeds especially most herbivores, so far they have inadequate cellulase in their digestive system, making them unable to digest fiber foods.

\section{Conclusions}

In conclusion, as most of the studies on cellulose production have been from cotton linter and wood pulp, each of these is a "natural" source, cotton is a valued added crop with a high cost of production and wood pulp utilization leads to deforestation, this research work contributes to a new and alternative source of cellulose. Cellulose from PKC if harnessed properly could be a better, cheaper and readily available source of cellulose for the production of cellulose derivative (CMC). This implies that palm kernel cake cannot only serve as animals feed but also a source of valuable raw materials to the industries.

It is recommended that purity test be carried out on cellulose derivative (CMC) before they could be incorporated into edible products.

\section{Acknowledgements}

Our acknowledgement goes to the department of Applied Biochemistry, Nnam- 
di Azikiwe University Awka, Anambra State, Nigeria and Mr., and Mrs. Honorable Moses Ezea for their supports during the research work.

\section{Conflicts of Interest}

The authors declare no conflicts of interest regarding the publication of this paper.

\section{References}

[1] Othmer, K. (2004) Encyclopedia of Chemical Technology. 4th Edition, Wiley and Sons Inc., New York, Vol. 5, 236-246.

[2] Dauenhauer, A., Krumm, C. and Pfaendtner, J. (2016) Millisecond Pulsed Films Unify the Mechanisms of Cellulose Fragmentation. Chemistry of Materials, 28, 3108-3114. https://doi.org/10.1021/acs.chemmater.6b00580

[3] Watanabe, H. and Tokuda, G. (2001) Animal Cellulases. Cellular and Molecular Life Sciences, 58, 1167-1178. https://doi.org/10.1007/PL00000931

[4] Watanabe, H., Noda, H., Tokuda, G. and Lo, N. (1998) A Cellulase Gene of Termite Origin. Nature, 394, 330-331. https://doi.org/10.1038/28527

[5] Bignell, D.E., Roisin, Y. and Lo, N. (2011) Biology of Termites: A Modern Synthesis. Springer, Dordrecht. https://doi.org/10.1007/978-90-481-3977-4

[6] Pickard, M.D. (2005) By-Products Utilization. In: Bailey’s Industrial Oil Products, 6th Edition, Volume 4, Edible Oil and Fat Products. Products and Applications, Wiley-Interscience, Hoboken, 46-66. https://doi.org/10.1002/047167849X.bio081

[7] Bono, A., Ying, P.H., Yan, F.Y., Muei, C.L., Sarbatly, R. and Krishnaiah, D. (2009) Synthesis and Characterization of Carboxymethyl Cellulose from Palm Kernel Cake. Advances in Natural and Applied Science, 3, 5-11.

[8] Bali, G., Meng, X., Deneff, J.I., Sun, Q. and Ragauskas, A.J. (2015) The Effect of Alkaline Pretreatment Methods on Cellulose Structure and Accessibility. ChemSus Chem, 8, 275-279. https://doi.org/10.1002/cssc.201402752

[9] Voravadee, S., Pranut, P. and Duandao, A. (2016) Preparation and Characterization of Microcrystalline Cellulose from Cellulose Based-Agro Waste. Journal of Engineering and Applied Science, 11, 2566-2572.

[10] Ambjornson, H.A., Schenzel, K. and Germgard, U. (2013) Carboxylmetyl Cellulose Produced at Different Mercerization Conditions and Characterized by NIR FT Raman Spectroscopy in Combination with Multivariate Analytical Methods. Biological Resources, 8, 1918-1932. https://doi.org/10.15376/biores.8.2.1918-1932

[11] Hong, L.T.R., Borrmeister, B., Dautzenberg, H. and Philip, B. (1978) Zur ermittlung des substitutions grades loslicher Carboxylmethylcellulose durch polyelektrolyt titration. Zellstoff und papier 207-210.

[12] Association of Official Analytical Chemists (AOAC) (1990) Official Methods of Analysis. 15th Edition, Washington DC, 67-89.

[13] SON/NIS 574 (2008) Physico-Chemical Analysis Specification. Institute of Public Analysis of Nigeria, Decree No. 100 of 1992.

[14] Ozioko, P.C., Eze, S.O.O. and Chilaka, F.C. (2013) Partial Purification and Characterization of Cellulases from Digestive Tracts of the African Giant Snail (Achatina achatina). Turkish Journal of Biology, 37, 1205-1211.

[15] Miller, G.T. (1992) Living in the Environment. The Annenberg/CPB Project. 
[16] Ohwoavworhua, F.O. and Adelakun, T.A. (2010) Non-Wood Fibre Production of Microcrystalline Cellulose from Sorghum caudatum: Characterisation and Tableting Properties. Indian Journal of Pharmaceutical Science, 72, 295-301. https://doi.org/10.4103/0250-474X.70473

[17] Latif, A., Anwar, T. and Noor, S. (2006) Two Step Synthesis and Characterization of Carboxylmethyl Cellulose from Rayon Grade Woods Pulp and Cotton Linter. Journal of Chemistry, 29, 143-150.

[18] Mark, H.F., Bikales, N.M., Overberger, C.G. and Meufe, G. (1985) Encyclopedias of Polymer Science and Engineering. 3rd Edition, John Wiley and Sons, New York, 326-340.

[19] Silva, D.A., de, R.C.M., Paula, P.A., Feitosa, A.C.F., de Brito, J.S. and Maciel, H.C.B. (2004) Carboxymethylation of Cashew Tree Exudates Polysaccharide. Carbohydrate Polymer, 58, 163-171. https://doi.org/10.1016/j.carbpol.2004.06.034

[20] Varshney, V.K., Gupta, N., Sanjay, K., Ritu, A. and Amit Bhatt, P.L. (2006) Carboxymethylation of a-Cellulose Isolated from Lantana Camara with Respect to Degree of Substitution and Rheological Behavior. Carbohydrate Polymer, 63, 40-45. https://doi.org/10.1016/j.carbpol.2005.07.001

[21] Togrul, H. and Arslan, N. (2003) Production of Carboxymethyl Cellulose from Sugar Beet Pulp Cellulose and Rheological Behavior of Carboxymethyl Cellulose. Carbohydrate Polymer, 54, 73-82. https://doi.org/10.1016/S0144-8617(03)00147-4

[22] Rosnah, M.S., Gapor, A.B., Top, M.D. and Hassan, W.H.W. (2004) Production of Carboxymethyl Cellulose (CMC) from Oil Palm Empty Fruit Bunch (EFB). Malaysian Palm Oil Board Information Series, No. 12, 1511-7871.

[23] Heinze, T. and Pfeiffer, K. (1999) Studies on the Synthesis and Characterization of Carboxylmethyl Cellulose. Macromolecular Chemistry and Physics, 266, 1-37. https://doi.org/10.1002/(SICI)1522-9505(19990501)266:1<37::AID-APMC37>3.0.C $\underline{\mathrm{O} ; 2-\mathrm{Z}}$

[24] Asep, H.S., Linnisa, Q. and Alia, B.P. (2014) Synthesis and Characterization of Carboxymethyl Cellulose (CMC) from Water Hyacinth Using Ethanol-Isobutyl Alcohol Mixture as the Solvents. International Journal of Chemical Engineering and Applications, 5, 36-40. https://doi.org/10.7763/IJCEA.2014.V5.347 